duced when the natural skylights are blacked out. The absence of distracting dazzle and the avoidance of glare raise and maintain the output of the factories.

\section{War-Time Museum Exhibitions}

The Museums Journal of May shows in what way many museums in Great Britain are endeavouring to stimulate interest by supplying information bearing upon warfare or upon the needs which it has created. In the former group is the special war-time exhibition at the National Maritime Museum, described by Sir Geoffrey Callender. Two contrasting sets of medals are shown, one German and one wrongly described as "English", for the only representative mentioned is "the General Service Medal conferred on British officers and men" during the Napoleonic wars. Lightship and lifeboat models, models showing the story of the development of the torpedo-boat, and of the evolution of anchors from their simple beginnings as heavy stones, are arranged with larger exhibits such as that illustrating the evolution of naval ordnance, to make a varied show which as a whole illustrates "the age-long character of our sea-experience and the continuity of our maritime prestige". "The second type of exhibit has been created in several museums "to show how the various kinds of foods, essential to man's existence, may be provided by vegetables and grown on a small allotment or in a garden". Several illustrations indicate how, by models of garden plots and cropping plans, this good work may be pursued.

\section{Investigation of Atmospheric Pollution}

RePResentatives of local authorities and other bodies co-operating in the investigation of atmospheric pollution met in London on May 28. The Conference, in considering its annual report to the co-operating bodies, unanimously agreed that while contribution to the war effort is the first duty and desire of every organization, the need for vigilant attention to the purity of the atmosphere has by no means decreased since the outbreak of the War. The wasteful burning of fuel, and the detriment which pollution causes to the nation's health were stressed. The Conference therefore urged all local authorities to do whatever lies in their power to maintain the investigation. At the close of the meeting, Prof. W. H. Roberts, associate professor of public health chemistry in the University of I.iverpool, was unanimously elected chairman of the Conference.

\section{Electricity Applied to Metallurgy}

IN the Menelaus Memorial Lecture delivered to the South Wales Institute of Engineers on March 19, Dr. A. P. M. Fleming chose as his subject "Electricity as applied to Metallurgy". A most important application arises in connexion with methods of testing. Dr. Fleming points out that electricity has proved an invaluable aid to the metallurgist when making fine measurements and researches, as well as for checking the quality of his materials. Using standardized specimens the composition and heat treatment of which are known, comparisons may be made of unknown specimens by magnetic testing. By suitable exploration of the magnetic behaviour of the specimen in an alternating magnetic field, it is possible to relate the phase and quadrature components of the voltage induced in a search coil, and by comparing these with the standardized specimen, definite inferences can be drawn as to the composition of the material without the necessity of destroying the specimen under test.

Magnetic methods have also been developed for fault detection, and have been of increasing importance due to the tendency to cut down material costs and weight, while still maintaining the safety factor, by more rigid inspection and care in production. The presence of a fault or change in magnetic composition can be detected by the distortion these cause in the magnetic field, the distortion being located either by a direction indicator like a magnetic needle or a moving search coil. Another and most valuable method is that developed largely by the MetropolitanVickers Electrical Co., Ltd., in which the specimen is magnetized and then subjected to examination under a coating of liquid containing very finely divided magnetic particles. When examining material in the shape of a bar for longitudinal cracks, a heavy current is passed down the bar while it is immersed in a bath of finely divided magnetic particles, suspended in a light oil. These particles form sharply defined lines which indicate the flaws. This method is of growing importance, and is probably the most effective means at present available of checking this form of weakness in metals.

\section{Incorporated Municipal Electrical Association}

THE activities of the Incorporated Municipal Electrical Association (I.M.E.A.) are described in the Electrical Review of May 10. The Association is taking steps to ensure that stocks of coal held by public utility undertakings in Great Britain shall be built up during the coming months to ensure that by September 30 the undertakings will have not less than ten winter weeks supply on hand. The Council has agreed that a scheme of insurance in respect to war damage to electricity undertakings should be prepared and has referred the matter to the Joint Committee of Electricity Supply Associations. The members of the Association have been recommended by the National Whitley Council to grant a temporary increase of salary to administrative, technical and clerical staffs. The Joint Committee of Electricity Supply Associations has approached the Minister of Home Security with a view to the relaxation of the restrictions upon the use of neon and other outdoor signs during hours of daylight.

The Finance Officer of the London and Home Counties J.E.A. (Mr. A. L. Burnell) recently prepared a memorandum on the transfer of hire-purchase agreements from one authority to another upon the removal of a consumer when he is unable immediately to complete payment. Difficulties are raised by the varying practice among undertakings in such matters as maximum periods, interest-rates, local limitations as to the type of apparatus and absence of hire 
purchase facilities in some areas, but all of these can be surr junted. Mr. Burnell suggests that all undertakings should be prepared to take over agreements on the original terms.

\section{Cancer Research and Treatment in Australasia}

THE Tenth Australian - New Zealand Cancer Conference, held at Wellington in February of last year, was concerned with cancer control, reports on particular forms of treatment (Koch and Baker) and radiological physics. The part being played by the physicist in the use of $\mathrm{X}$-rays and radium is a rapidly growing one; this arises from the growth of quantitative methods in giving doses of radiation to patients. These methods not only allow the specification of the dose actually given, but also they aim at arranging for the optimum distribution of the radiation throughout the tissues. The report from the Commonwealth X-ray and Radium Laboratory shows a wide range of activity at this centre, with a most progressive outlook as to the function of the physicist in collaboration. It is good to learn that the Commonwealth Department of Health has made the services of the physicists-in-charge available to radiotherapeutic institutions for consultation on the various physical problems of X-ray and radium therapy, and advantage is being taken of such facilities, doubtless to the benefit of patients.

\section{American Zeal for Education}

School and college summaries seem perpetual in the United States. "A Review of Educational Legislation : 1937 and 1938", by Mr. Ward Keesecker (Washington, D.C., 10 cents), has involved, we are told, a study of 1,500 enactments. The main tendencies exhibited are increased support from the State with more control and the establishment of minimum State-aid foundations. Pennsylvania in 1937 paid special attention to local schools, county boards of directors, the merging of schools poorly attended, and transportation routes. In Georgia all teachers now have to be classified according to their training and experience. In Nevada, amendment of the liquor-licence law increased the amount set aside for education. Tennessee added $4 \frac{1}{2}$ million dollars to school funds. Two States, Arkansas and Vermont, made teaching on the effects of alcohol compulsory from grades 3 to 8 . Montana required all public schools to give instruction in music, art, and elementary agriculture. Several States increased the minimum salaries of teachers and their benefits on retirement, and Kentucky forbade city schools to discriminate against married women as teachers. It is clear that throughout the country great pains have been taken to see that education is better managed and financed.

\section{Smithsonian Institution: Annual Report}

THE report of the secretary of the Smithsonian Institution for the year ended June 30, 1939, which has been published, refers to the completion by the Astrophysical Observatory of the enormous task of recomputing the daily solar constant values from all its observing stations since 1923, apart from the final corrections and general discussion, which were expected to be concluded by October 1939. The Division of Radiation and Organisms gave much attention during the year to photosynthesis, factors influencing plant growth and the stimulative action of ultra-violet radiation. Experimental evidence was obtained indicating the formation during photosynthesis of a material which combines with or absorbs carbon dioxide and resembles chlorophyll in character. A quantitative method for the isolation of hormones from plants is being developed, and the effect of radiation on the growth of excised roots and leaves has been investigated.

Numerous scientific field investigations in anthropology have been conducted by the National Museum as well as archæological and ethnological expeditions by the Bureau of American Ethnology, including investigations of Folsom man at the Lindenmeier site in northern Colorado, studies in the northern province of the Navaho Indians, as well as in western South America. In addition to the report of the Executive Committee of the Board of Regents, appendixes include detailed reports of the work of the various divisions, including the National Gallery of Art, the Freer Gallery of Art, the National Collection of Fine Arts and the National Zoological Park, the last-named giving a detailed list of animals in the collection that had not previously been exhibited.

\section{Awards of the Finney-Howell Research Foundation}

The Finney-Howell Research Foundation, Inc., of Baltimore, Maryland, announces that fellowships for research into the cause or causes and the treatment of cancer were renewed for the following: P. C. Aebersold, working at the Radiation Laboratory of the University of California at Berkeley; G. M. Badger, working at the Royal Cancer Hospital (Free) at London, England; L1. W. Law, working at the Roscoe B. Jackson Memorial Laboratory at Bar Harbor, Maine; J. L. Melnick, working at Yale University School of Medicine at New Haven, Conn.; J. F. Menke, working at Stanford University Hospital, at San Francisco, California; J. L. Wood, working in the Division of Chemistry, Harvard University, at Cambridge, Mass.; P. C. Zamecnik, working at Copenhagen. New fellowships have been awarded as follows: J. C. Abels, to work at the Memorial Hospital for Cancer at New York City; M. A. Graubard, to work at Clark University, Worcester, Mass. ; J. W. Howard, to work at Thorndike Memorial Laboratory, Boston City Hospital, Boston, Mass.; B. E. Kline, to work at the Department of Physiology, University of Wisconsin, Madison; Margaret $\mathrm{N}$. Lewis, to work at Crocker Radiation Laboratory, University of California, Berkeley; A. Marshak, to work at the Radiation Laboratory, University of California, Berkeley; Dr. G. C. Gey was also awarded a grant of 2,000 dollars to carry on his work on cancer at the Johns Hopkins Medical School. The closing date for applications for awards during 1941 is January $1,1941$. 